\title{
A Igreja Católica perante a Modernidade: uma análise das encíclicas papais no século XIX
}

\author{
Ana Rosa Cloclet da Silva* \\ Estela Maria Frota da Costa**
}

\section{Resumo}

Este artigo analisa o conteúdo discursivo das encíclicas emitidas pelos pontificados de Gregório XVI (1831-1845), Pio IX (1846-1878) e Leão XIII (1878-1903), considerando tais enunciados expressivos de algumas das adaptações impostas à Igreja católica às transformações que marcaram o advento da sociedade moderna e secular. Baseandose na metodologia da Análise de Discurso, procura demonstrar em que medida tais documentos nos colocam em contato com as estratégias trilhadas por estes papas em resposta às contingências de sua época. Com isto, definiram uma "autocompreensão eclesial" e sobre a missão da Igreja católica no mundo moderno, tornando a Instituição um ator dinâmico da própria construção da modernidade, ainda quando em reação a algumas de suas dimensões.

Palavras-chaves: Igreja católica; Modernidade; Secularização; Encíclicas papais; autocompreensão eclesial

* http://orcid.org/0000-0001-7612-1130. URL http://lattes.cnpq.br/6648577383927409. Pontifícia Universidade Católica de Campinas (PUC-Campinas). É docente da Faculdade de História da PUC-Campinas (desde 2008) e do Programa de Pós-Graduação Stricto Sensu em Ciências da Religião, pela mesma Universidade (desde 2012), com projetos integrados à Linha de Pesquisa: "Fenômeno Religioso: instituição e práticas discursivas". É doutora em História pela Universidade Estadual de Campinas - UNICAMP (2000) e pós-doutora na mesma área pela Universidade de São Paulo - USP (2007). anacloclet@gmail.com .

** http://orcid.org/0000-0002-2195-8774. URL http://lattes.cnpq.br/1921644640799125. Pontifícia Universidade Católica de Campinas (PUC-Campinas). Mestre em Ciências da Religião pela Pontifícia Universidade Católica de Campinas. Licenciada em História pela Universidade Metodista de Piracicaba. denisesbofrota@hotmail.com . 


\title{
The Catholic Church front of Modernity: an analysis of papal encyclicals in the 19th century
}

\begin{abstract}
This article analyzes the discursive content of the encyclicals issued by the pontificates of Gregory XVI (1831-1845), Pius IX (1846-1878) and Leo XIII (1878-1903), considering such statements as expressive of some of the adaptations imposed on the Catholic Church to the transformations that marked the advent of modern and secular society. Based on the Discourse Analysis methodology, it seeks to demonstrate how such documents put us in contact with the strategies pursued by these popes in response to the contingencies of their time. In this way, they defined an "ecclesial selfunderstanding" and about the mission of the Catholic Church in the modern world, making the Institution a dynamic actor in the construction of modernity, even when in reaction to some of its dimensions.
\end{abstract}

Keywords: Catholic Church; Modernity; Secularization; Papal encyclicals; ecclesial self-understanding

\section{La Iglesia católica frente a la modernidad: un análisis de las encíclicas papales en el siglo XIX}

\section{Resumen}

Este artículo analiza el contenido discursivo de las encíclicas emitidas por los pontificados de Gregorio XVI (1831-1845), Pío IX (1846-1878) y León XIII (1878-1903), considerando dichos discursos expresivos de algunas de las adaptaciones impuestas a la Iglesia católica a las transformaciones que marcaron el advenimiento de la sociedad moderna y secular. A partir de la metodología del Análisis del Discurso, busca demostrar cómo dichos documentos nos ponen en contacto con las estrategias que persiguen estos papas ante las contingencias de su tiempo. De esta manera, definieron una "autocomprensión eclesial" y sobre la misión de la Iglesia católica en el mundo moderno, haciendo de la Institución un actor dinámico en la construcción de la modernidad, aun cuando sea en reacción a algunas de sus dimensiones.

Palabras clave: Iglesia Católica; Modernidad; Secularización; Encíclicas papales; autocomprensión eclesial

\section{Introdução}

Desde meados do século XVIII, as sociedades ocidentais foram convulsionadas por acontecimentos atestadores da progressiva falência das formas e mecanismos até então capazes de reiterar a normalidade da vida política e social nos moldes do Antigo Regime, submetido à crítica intelectual que estivera na gênese do mundo moderno e secular.

No âmbito de tensões desde antes acumuladas e de transformações acentuadas, sobretudo, a partir da Revolução Francesa - evento "que afetou 
o mundo inteiro, extensivamente, e todos os homens, intensivamente" (KOSELLECK, 1999, p. 10) - as sociedades ocidentais vivenciaram a emergência de uma nova percepção subjetiva do tempo, mediante a qual as experiências passadas tornavam-se cada vez menos pertinentes para pautar o presente e projetar expectativas de futuro. Segundo Koselleck, este tempo acelerado constitui umas das principais marcas da modernidade, de tal forma que, "só se pode conceber a modernidade como um tempo novo a partir do momento em que as expectativas passam a distanciar-se cada vez mais das experiências feitas até então". (KOSELLECK 2006, p. 314)

Diferentes teóricos da modernidade tem reconhecido esta sensação de ruptura com a continuidade, a pretensão de rejeitar tradição, o dinamismo imposto por mudanças incessantes e a imprevisibilidade que daí resulta como principais características da nova consciência moderna, bem como assumido alguns dos seus impactos sobre a religião. Segundo o teólogo Gianni Vattimo: "A Modernidade desenvolve e elabora em termos puramente mundanos e seculares a herança hebraico-cristã, com uma visão da história como progresso", mediante a qual "a sociedade começa a se tornar autônoma em relação à Igreja e à religião, atingindo o auge com o Iluminismo e com a Revolução Francesa. (VATTIMO, 2002, p. VIII-XI e p. 64)

Portanto, num campo oposto ao que estruturava a sociedade medieval fundamentada sobre as verdades de fé e da iluminação divina -, compreenderse moderno significa assumir a razão como forma privilegiada de produção do conhecimento, da sua submissão à experimentação e da rejeição aos paradigmas que compunham a tradição anterior, cujas diretrizes derivam, em grande parte, da filosofia escolástica e da relação harmônica entre fé e razão. O resultado, dentre tantos outros, seria a crença na capacidade do homem de alcançar a perfeição dentro dos limites da temporalidade, libertando-o de maneira progressiva da tutela divina. (CALDEIRA, 2017, p. 776)

Esta consciência pautada na emergência de uma nova qualidade do tempo - "transcendente à natureza e imanente à história" (KOSELLECK 2006 , p. 55) - informara, assim, a relação entre religião e modernidade, definida pelo conceito de "secularização". Segundo Coelho:

A gestação desse conceito ocorre no confronto social entre a ambição totalizadora da religião como horizonte de compreensão da integralidade da vida e o projeto unificador pela razão que, ao mesmo tempo em que desconstrói as totalidades religiosas, pretende explicar leis e regularidades que regem o mundo. (COELHO, 2016, p. 86) 
Tal embate impôs o ajuste da religião a fenômenos produzidos em planos que dela começavam a se diferenciar e que atestavam a perda da sua capacidade normativa, engendrando combinações inéditas entre o religioso e o secular. $\mathrm{O}$ que significa que, para manter-se influente e continuar moldando a consciência moderna, a religião seguiu redefinindo de forma permanente "seus respectivos espaços e margens de ação e impondo-se mutuamente determinadas modalidades de presença na vida dos individuos e das comunidades, transformando suas relações com o sagrado, com as instituições religiosas e destas com a política, a sociedade e a cultura", delineando contextos de “modernidade religiosa". (DI STEFANO, 2018, p. 135) ${ }^{1}$

No caso das sociedades ocidentais, profundamente tributárias do catolicismo como matriz civilizacional, tal processo impôs à Igreja católica permanentes adaptações às transformações em outras esferas da realidade, o que repercutiu tanto em nível do discurso oficial da Instituição, quanto nas estratégias trilhadas pelos seus representantes, ao longo do século XIX. Nestes termos, a Igreja católica, longe constituir um elemento atávico no processo de construção das sociedades modernas e seculares (STEIL; HERRERA, 2010), revelou-se ator importante deste mesmo processo, que a envolve e, ao mesmo tempo, modifica-se por esse envolvimento.

Atentos a estas remodelações recíprocas entre o religioso e o secular, o presente artigo tem como objetivo analisar de que maneira e em que medida o discurso oficial da Igreja católica, representado pelas encíclicas emitidas pelos pontificados de Gregório XVI (1831-1845), Pio IX (1846-1878) e Leão XIII (1878-1903), revela-se expressivo de algumas das conexões básicas e essenciais entre a Instituição e as transformações socioculturais que marcaram o advento da modernidade ocidental. Especificamente, ao considerar a influência das contingências vivenciadas nas decisões institucionais e na própria autoimagem que a Igreja formula sobre si - a partir da qual define historicamente sua intervenção na sociedade -, a análise das encíclicas papais emitidas durante o século XIX nos coloca em contato com a própria "autocompreensão eclesial", a qual, segundo Ivan Manoel, corresponde à atuação institucional da hierarquia eclesiástica, mediante a qual o Papa "define um conceito de Igreja, estabelece suas tarefas e estratégias de ação e reordena sua política interna em função de seu projeto político e pastoral externo", derivando uma "forma de autoentendimento" que permanece vigente "até ser substituída por

Tradução minha, do original em espanhol. 
A Igreja Católica perante a Modernidade: 335 uma análise das encíclicas papais no século XIX

outra, gerada nas suas próprias contradições internas e externas". (MANOEL, 2004, p. 10)

Portanto, ao editar tais documentos, cada pontífice definiu objetivos e estratégias de ação institucionais, reveladoras da maneira como esta hierarquia recepciona e interpreta o mundo ao seu redor, ao mesmo tempo que incorpora e reelabora a concepção eclesial acumulada ao longo dos demais pontificados, autoconferindo-se "tarefas, obrigações e papéis sociais bastante específicos” (MANOEL, 2004, p. 10). Tal dinâmica nos permite conceber a historicidade da fabricação dos discursos religiosos, bem como da própria Igreja católica, filiando o presente artigo ao enfoque renovado da História Eclesiástica, que concebe a Igreja como "instituição ou como uma profecia institucionalizada", portadora de "uma autonomia e uma vida interna", mas cujas "regras nascem de uma interação contínua (tanto no plano cultural como da vida quotidiana) entre os indivíduos e as instituições que gerenciam o poder". (PRODI apud SANTIROCCHI, 2017, p. 172)

Ao mesmo tempo que instituem marcos na história eclesiástica ${ }^{2}$, as encíclicas papais aqui analisadas constituem registros importantes da experiência temporal que marca a modernidade, ao expressarem uma nova forma de articulação entre passado e futuro pela hierarquia eclesial. Afinal, o que singulariza cada um dos pontificados analisados é, justamente, o poder de elaborar acontecimentos passados, bem como ressignificar a tradição teológica herdada, a partir de circunstâncias presentes e em boa medida inéditas. Ao fazê-lo, abrem um novo campo de ação e previsões, capaz de liberar expectativas que já não "decorrem apenas da experiência" (KOSELLECK, 2006, p. 313), antecipando um futuro em que a religião e a Igreja assumem novos papéis e uma nova funcionalidade.

Do ponto de vista metodológico, a análise destas encíclicas mobiliza o instrumental da Análise do Discurso ${ }^{3}$, que tem se revelado operacional para os

2 Esta autocompreensão Ivan Manoel divide-a em três períodos: entre 1800 a 1878 , compreendendo os pontificados de Gregório XVI e Pio IX, nos quais se consolida a doutrina conservadorista por meio do discurso. O segundo momento compreende todo o pontificado de Leão XIII, entre 1878 a 1903, onde as decisões em nome da intervenção na realidade concreta é conjugada à doutrinação contra o mundo moderno. Na terceira fase, há a transformação da doutrina em prática: abrange os pontificados de Pio X a Pio XII, entre 1903 a 1958, cujas contradições encaminharam a convocação do Concílio Vaticano II. (MANOEL, 2004, p. 12).

3 Sobre o método da Análise de Discurso Religioso, utilizamos: BRANDÃO (2004), SILVA; COSTA (2011); ORLANDI (1996) (2013); ZANOTTO (2018). 
estudos de religião. Trata-se de interpretar o discurso pressupondo a presença de elementos que o extrapolam, articulando o texto, as práticas discursivas e as práticas sociais "que lhe servem de suporte, reforço, oposição e que balizam suas normas, concepções e costumes” (ZANOTTO, 2018, p. 347). Além disso, a Análise de Discurso considera que a "sequência discursiva" deve ser analisada enquanto processo de "reprodução/transformação dos enunciados no interior de uma formação discursiva dada" (BRANDÃO, 2004, p. 52). Desse modo, ao remeter o estudo intradiscurso ao campo interdiscursivo, tal instrumental nos permite inscrever o objeto deste estudo na sua diacronia, salientando as rupturas e continuidades discursivas entre os pontificados analisados.

\section{A universalização da Igreja católica na modernidade}

A dinâmica de universalização católica na modernidade implicou estratégias voltadas, necessariamente, para a contenção da diversidade na unidade. Segundo Carlo Fantappiè, tal movimento se deu por conexões realizadas a partir da normatização, da aplicação dos documentos institucionais, das cartas, das pessoas, dos objetos e dos hábitos que circulavam por diferentes espaços do globo. Todos esses, segundo o autor, aspectos que nos reportam à relação entre o universal e o local, sendo cruciais para manter a multiplicidade na unidade. (FANTAPPIÈ, 2012, pp. 332-333) ${ }^{4}$

Especificamente, é possível destacar três estratégias utilizadas pela hierarquia católica para a universalização do catolicismo: a normatização, a comunicação e a flexibiliz̧ação. Segundo Fantappiè, o regulamento (norma) é o que permite a unidade e continuidade no tempo da própria Igreja institucional, tendo sido implementado por meio de figuras e instrumentos informativos específicos, representados pelas nunciaturas e os núncios, assim como pelas bulas, cartas encíclicas, etc. (FANTAPPIÈ, 2012, p. 334). Entretanto, a fim de conter as tensões entre os diferentes contextos e conseguir a unidade religiosa, a estrutura central e a normativa deve proceder a uma permanente flexibilização, combinando, durante toda a época moderna, “a adaptação e o disciplinamento". (FANTAPPIÈ, 2012, p. 335)

Estas estratégias de universalização do catolicismo na modernidade se reconfiguram no decorrer do século XIX, encontrando nas encíclicas emitidas pelos pontífices Gregório XVI, Pio IX e Leão XIII algumas de suas mais

Tradução minha, do orginal em italiano. 
eloquentes formas de enunciação. Enquanto modalidades de discurso religioso, as encíclicas são compostas por graves exortações e advertências sobre a doutrina destacada pelo pontífice (WERNZ-VIDAL apud BARNABÉ, 2011, p. 274), o qual se coloca como mediador da voz de Deus, ao mesmo tempo em que se submete ao disponibilizar sua voz para que Deus fale através dele (ZANOTTO, 2018, p. 351). A coerência do discurso é dada pelo uso das escrituras e de outros conteúdos que compõem a Tradição escriturária, através do recurso à interdiscursividade e à intertextualidade (SILVA; COSTA, 2011, p. 130), evocando, desse modo, recurso comum à historiografia eclesiástica de vertente eusebiana, segundo a qual a conformidade com as origens é prova da veracidade do discurso. (MOMIGLIANO, 2004, p. 192)

Ao elaborar e emitir os conteúdos discursivos das encíclicas, portanto, a Igreja católica se coloca como ator do processo de transformações que a envolve e, ao mesmo tempo, modifica-se pelo seu envolvimento. O que implica assumir que a Instituição é, também, portadora de um projeto de modernidade, o qual, segundo Paolo Prodi (2010), esteve tradicionalmente ancorado no que o autor denomina de "paradigma tridentino": uma espécie de recorte de longa duração marcante na história da Igreja, desde os eventos que provocaram a crise do Medievo até o Vaticano II.

Esta estrutura toma como parâmetro as decisões do Concílio de Trento (1545-1563) em resposta às mudanças ocorridas na sociedade (SANTIROCCHI, 2017), mas não o faz de maneira uníssona: trata-se de um projeto plural, com várias descontinuidades, propostas e respostas à modernidade. As variáveis podem ser os papas, as situações e as estratégias empregadas, sendo que as descontinuidades no paradigma contribuem para a compreensão da Época Moderna em sua pluralidade. O "paradigma tridentino" teria, assim, marcado a história da Igreja por todo esse longo período, no decorrer do qual o processo de "modernização" abriu caminho para aquele da "secularização", existindo projetos concorrentes de modernidade.

Durante o processo de formação e fortalecimento dos Estados modernos, a Igreja tentou frear a sua perda de poder supranacional na Europa, por meio da centralização da cúria romana e pelo poder indireto do pontífice nos negócios temporais. Desse modo, à medida que “o Estado moderno não precisou mais da unidade religiosa como base ideológica, promovendo ele mesmo a nova religião da pátria” (PRODI apud SANTIROCCHI, 2017, p. 175), a Igreja procurou estabelecer e fortificar uma soberania paralela e universal, por meio de um corpo eclesiástico 
supranacional e supraestatal, com uma nova disciplina do clero, e pelas estratégias voltadas para o controle das consciências. Esta concorrência de propostas de modernidade entre a Igreja e os Estados acabou acirrando, e por vezes radicalizando, a "autonomização" das esferas. Nesse sentido, mesmo que de forma negativa - como reação - a atuação da Igreja contribuiu para o avanço desse processo, enquanto em outras ocasiões o freou.

Dentre os papados que atravessaram o século XIX - quando o advento da modernidade política esteve marcado por profundas mutações nas noções de soberania e representação (XAVIER-GUERRA, 2009) as posturas reativas à modernidade, que anatemizaram algumas de suas tendências e buscaram frear o processo de autonomização da esferas em relação à religião, foram emblematicamente representadas pelos pontificados de Gregório XVI (1831-1845) e, principalmente, Pio IX (1846-1878), cujas encíclicas estiveram profundamente vinculadas ao "paradigma tridentino", conforme passaremos a analisar.

\section{$\mathrm{O}$ "paradigma tridentino" como reação à modernidade}

No decorrer dos séculos, o discurso oficial da Igreja Católica Apostólica Romana assume centralidade, instituindo-a como realidade diferenciada da sociedade e desenvolvendo uma estrutura de imunidade ao redor dos pontífices e da Instituição, no âmbito da qual documentos eram falsificados e leis estatais submetidas a análises canônicas em nome da superioridade papal. Desse modo, fundamentava-se, por um lado, o "domínio absoluto do papa no âmbito da Igreja e, por outro, o direito autônomo e a jurisdição da Igreja perante o Estado." (KÜNG, 2012, p. 90)

Desde o fim do Império Napoleônico e da instauração do Congresso de Viena (1815), tais princípios e estratégias foram retomados pela hierarquia da Igreja romana, orientando o clima de restauracionismo das antigas legitimidades monárquicas, o dogma da infalibilidade do poder papal e a identidade da Igreja católica como instituição. De tal forma que, em reação aos princípios deflagrados pela Revolução Francesa e que, em boa medida, inspirariam as revoluções liberais, democráticas e nacionalistas do século XIX (RÉMOND, 1997, p. 14), houve a busca de um novo "centro" supostamente capaz de "proteger os membros da comunidade clerical" e associado à "função e às prerrogativas do Sumo Pontífice", em detrimento do poder do Estado. (SANTIROCCHI, 2015, p. 196) 
Em todo o mundo católico da época, esta reação oficial da Igreja católica encontrou apoiadores e precursores, que se opuseram ao avanço da mentalidade do tempo, marcada pelo liberalismo, pelo racionalismo e pelo avanço da secularização, vistos como supostos males plantados pela Revolução de 1789, sob os quais constituía-se, progressivamente, um "mundo estranho à Igreja", que combatia "as tradições por ela transmitidas há séculos". (COMBY, 1994, p.166)

Por meio da institucionalização da "Ideologia da Cristandade" fundamentada no conceito de "sociedade perfeita", que valoriza o aspecto institucional da Igreja, servindo de modelo para ordenar a sociedade civil e a vida cotidiana (ZAGHENI, 2011 p. 79) - a Restauração se exprimia na oficialidade da Igreja, unindo a centralização, a clericalização e os discursos espiritualizantes fortemente vinculados à Tradição escriturária, que caracterizam o ultramontanismo: termo polissêmico ${ }^{5}$, que no século XIX passa a designar:

$\mathrm{Na}$ esfera intelectual, a rejeição à filosofia racionalista e à ciência moderna; na política externa, a condenação à liberal democracia burguesa e o concomitante reforço da ideia monárquica; na política interna, o centralismo em Roma e na pessoa do Papa e o reforço no episcopado; na esfera socioeconômica, a condenação ao capitalismo e ao comunismo e um indisfarçável saudosismo a Idade média. (MANOEL, 2004, p.11)

É neste contexto que se pode compreender a orientação oficial da Igreja sob Mauro Capellari, eleito papa em meio às consequências da Revolução de $1830^{6}$, com o apoio da facção conservadora ${ }^{7}$, no conclave de

5 Segundo Santirocchi (2010) em latim sua tradução significa "para além dos montes", encontrando-se pela primeira vez no período medieval designando os pontífices não italianos; a expressão possuiu conotações que se referiam a intervenções estrangeiras: após a Reforma Protestante passou a identificar a interferência do Papa em questões temporais, visto como uma autoridade extraterritorial, posteriormente, àqueles que eram apontados como favoráveis ao reconhecimento da superioridade do poder pontifício no contexto da nacionalização das igrejas passaram a ser qualificados de maneira difamatória como "ultramontanos". (SANTIROCCHI, 2010, p. 24)

6 A Revolução de 1830 coloca fim nos esforços de restauração ao cenário anterior à 1789; apesar de ter início com a deposição do rei Carlos X em reação a medidas que cerceavam a liberdade de imprensa, a onda liberal-burguesa espalhou-se por grande parte da Europa, assumindo caráter nacionalista na Bélgica, na Polônia e no norte da Itália. Neste último caso, contra a influência austríaca e contra o domínio papal. Sobre isso, Cf: (COMBY, 1994); (DANIEL-ROPS, 2003); (HOBSBAWM, 2014)

7 Segundo Martina, os chamados cardeais “zelosos” já eram maioria no conclave que elegeu Leão XII em 1823. Este grupo defendia o poder temporal, a resistência às leis de laicização, defesa do direitos tradicionais da Santa Sé, nutrindo, sobretudo, desconfiança em relação ao mundo moderno. (MARTINA, 2005, p. 170) 
1831. Assume com o nome de Gregório XVI em um momento delicado da restauração, registrando especial preocupação com os conflitos ao norte da península itálica ${ }^{8}$ - pertencente aos Estados Pontifícios -, desencadeados por liberais insatisfeitos com a influência austríaca na região, fruto do compromisso estabelecido entre a Sé romana e a chamada Santa Aliança, estabelecida entre os representantes da Prússia, Áustria e Rússia no Congresso de Viena, em nome da legitimidade dos governantes depostos e da conservação dos princípios cristãos (COMBY, 1994, p. 104). Neste mesmo Congresso, os signatários voltam a reconhecer a diplomacia pontifícia e seu representante junto aos Estados como atores privilegiados nas negociações diplomáticas ${ }^{9}$. Desde então, as nunciaturas e a comunicação que estabeleciam com Roma constituem uma das estratégias de universalização da Igreja, bem como de controle disciplinar do clero e combate aos ataques dos "inimigos da religião e do trono”. (GREGÓRIO XVI, [1831] 1999, p. 11)

Após quase um ano de papado, Gregório XVI emite a encíclica Cum Primum Ad Aures, em 9 de junho de 1832, condenando os movimentos revolucionários na Polônia ${ }^{10}$, e passa a refletir sobre uma possível origem comum dos conflitos na Europa. A causa do crescimento das hostilidades, segundo Gregório, residiria no questionamento das autoridades legítimas, sendo necessário o trabalho dos bispos e arcebispos no reforço dos valores cristãos no clero e no povo, "vigiando com todos os meios, para que homens enganadores e sustentadores de novidades não continuem a difundir entre vossa grei doutrinas errôneas e falsos princípios" (GREGÓRIO XVI, 1999 [1832], p.21). Esta concepção, de fortes raízes tridentinas e moralizantes, fundamentava-se na Sagrada Escritura, segundo a qual a obediência às autoridades é um preceito divino, devendo ser respeitado sempre que as ações governamentais estiverem dentro dos limites dos ensinamentos cristãos.

Preocupação esta registrada nas encíclicas Aquele Deus e As armas valorosas. Cf: (GREGÓRIO XVI,[1831] 1999).

9 Segundo Anna Carletti, a autoridade da diplomacia pontifícia havia sido diminuída com a separação entre política e religião após o Tratado de Westfália em 1648. (CARLETTI, 2012, p. 18).

10 A Polônia constituía um território dividido entre Rússia, Prússia e Áustria desde o fim do século XVIII, e ratificado pelo Congresso de Viena em 1814. Por volta dos anos 1830, grupos poloneses incentivados por bispos e padres revoltaram-se contra os abusos por parte da Rússia, levando Gregório XVI a emitir uma encíclica acompanhada de uma carta lamentando a postura do Czar, porém, recomendando a submissão às autoridades constituídas, manifestando-se contrário a qualquer tipo de revolução e justificando a rebelião polonesa como uma revolta liderada por radicais e maçons. (MARTINA, 2005, p. 162; ZAGHENI, 2011, pp.116- 117) 
Além de defender a união entre a Igreja e outros Estados no controle das contendas liberais, Gregório XVI embateu-se fortemente contra outra tendência do século: a liberdade de consciência. Neste sentido, alimentou acalorada polêmica contra Félicité de Lamennais, expoente controverso do tradicionalismo católico francês ${ }^{11}$, que na defesa da libertação da Igreja da suposta proteção dos governos - que a teriam tornado "instrumento de sua política e joguete dos seus caprichos" (LAMENNAIS, apud, DANIEL-ROPS, 2003, p. 317) - fundou o jornal L'Avenir, em 1830, cujas teses foram alvo de críticas e censura pelo clero na França ${ }^{12}$ e pelo papa Gregório XVI, que em 15 de agosto de 1832 emitiu a Encíclica Mirari Vos.

Este documento repudia a linha editorial do jornal de Lamennais, podendo ser considerado a primeira sistematização das condenações da Igreja católica em relação ao mundo moderno. Segundo Gregório XVI:

A santidade das coisas sacras é desprezada, e a augusta majestade do culto divino, que possui grande força e influxo sobre o coração humano, indignamente é rejeitada contaminada e tornada objeto de escárnio por homens tratantes. Então se distorce e perverte a sã doutrina e se disseminam de modo audaz erros de todo gênero. Não há leis sagradas, nem direitos, nem instituições, e nem disciplinas por santas que sejam que se encontrem protegidas do ardil deles, que expelem apenas malvadezas de sua boca imunda. (GREGÓRIO XVI, 1999, p. 27)

A Encíclica resume importantes pontos da autocompreensão ultramontana, sendo direcionada a todos os bispos, diferentemente dos outros documentos promulgados até então por Gregório XVI, que versavam sobre temas circunstanciais. Sua "condenação do indiferentismo religioso e da liberdade de consciência, de imprensa e de pensamento" (GREGÓRIO XVI, [1832], 1999) inspirou as demais posturas enérgicas da Igreja frente ao mundo moderno, representando uma primeira formulação daqueles que passariam a ser considerados os "erros" da modernidade, posteriormente detalhados por Giovanni Mastai Ferretti - o papa Pio IX (1846-1878) -, que melhor elaborou e colocou em prática os ideais ultramontanos preconizados na Mirari Vos.

11 Sua trajetória se altera no curso das revoluções liberais, passando de uma fase estritamente ultramontana em defesa da infalibilidade papal, a uma fase passageira, na qual advoga pela separação entre Igreja e Estado e pela adesão católica à democracia e ao liberalism, tendo influenciado a porção intransigente e o catolicismo liberal (DANIEL-ROPS, 2003; ZAGHENI, 2011)

12 MARTINA, 2005, p. 193; DANIEL-ROPS, 2003, p. 272. 
Durante seu longo pontificado, considerado o mais duradouro até hoje, uma série de eventos históricos fez com que suas ações priorizassem a centralização da estrutura institucional da Igreja católica em torno da Sé romana e do Sumo Pontífice, bem como a valorização dos conteúdos doutrinários. O incremento da Cúria romana se deu mediante a criação de Dicastérios, fazendo com que este órgão essencial do governo da Igreja adquirisse "uma relevância ímpar na estrutura católica no século XIX", cabendo a ele "zelar rigidamente sobre todos os aspectos da Igreja enquanto instituição" (CONTIERO, 2017, p. 82). A centralidade curial se exprimia, ainda, na defesa da uniformidade da doutrina e da aplicação integral das decisões que eram emitidas pela Santa Sé, contra tudo aquilo que pudesse estimular a manutenção das diferenças regionais na vida eclesiástica, desencorajando-se as veleidades de reunir concílios nacionais, favorecendose a volta à "observação integral do direito canônico tal como ensinado em Roma", bem como "os recursos à cúria romana para qualquer tipo de questão, ainda que secundária” (AUBERT apud BATISTA, 2013, p. 60).

Logo na primeira encíclica promulgada por Pio IX - a Qui Pluribus, em 9 de novembro de 1946 - a ênfase recaía sobre o que era considerado um dos principais "Erros da época", atribuído aos excessos do racionalismo, que insistia em explicar a religião. A fim de que "os fiéis não sejam agitados por todo vento de doutrina, presos pela artimanha dos homens e de sua astúcia que nos induz ao erro", reivindicava que

Essa autoridade viva e 'infalível' vigora somente naquela Igreja que, edificada pelo Cristo Senhor sobre Pedro, cabeça, príncipe e pastor de toda a Igreja — cuja fé prometeu nunca faltar —, sempre teve, sem interrupção, os seus legítimos pontífices que remetem suas origens ao mesmo Pedro, postos sobre a cátedra deles, herdeiros e defensores da doutrina, da dignidade, da honra e do poder do mesmo. (PIO IX, [1846], 1999, p. 86)

Portanto, para defender os fiéis das correntes de pensamento em voga, Pio IX resgatava a autoridade da Instituição herdada pelos sucessores "do beatíssimo Pedro, na qual Cristo pôs o inexpugnável fundamento da sua Igreja" (PIO IX, [1846], 1999, p. 88). Em nome deste "fundamento", rogava aos bispos aos quais a Encíclica se dirigia: "favorecei em todos, a união com a Igreja católica, fora da qual não há salvação, e a obediência a esta cátedra de Pedro, sobre a qual se apoia, com seu solidíssimo fundamento, todo o edifício da nossa santíssima religião". (PIO IX, [1846], 1999, p. 91) 
Sob Pio IX, observa-se ainda o reforço da clericalização da Igreja, com ênfase no papel da hierarquia eclesial. Ao clero caberia a função de ensinar, santificar e governar - por atribuição do próprio Deus -, ao passo que aos fiéis restava "receber a doutrina, a santificação ${ }^{13}$ e as normas organizacionais numa passividade total". Outras características da clericalização registram-se na Qui Pluribus, tais como: o "jurisdicismo", que associa a autoridade segundo padrões jurídicos do Estado secular, segundo o qual o "direito canônico permeia o ensino, a santificação e o governo"; o "triunfalismo", que considera ser a Igreja a única instância a vencer o mal e o fundamento da autoridade na "tradição magisterial e escriturária". (CORDI, 1984, p. 34)

Caberia ao clero, portanto, manter a disciplina em suas ações notabilizando-se "pela seriedade dos costumes, integridade de vida, santidade e doutrina, e segundo as prescrições dos sagrados cânones" (PIO IX, [1846], 1999 , p. 93-94) -, assim como instruir o povo. Conforme registrado na encíclica Nostis et nobiscum, de 8 de dezembro de 1849, era preciso "fazer penetrar no coração de todos as sagradas palavras e as máximas de salvação, indicando-lhes com discursos breves e fáceis os vícios dos quais devem fugir e as virtudes que devem praticar para escaparem à pena eterna e para conseguirem a glória celeste.” (PIO IX, [1849], 1999, p. 135).

A centralização passava, também, pela tentativa de reunificar as Igrejas católicas ocidentais e orientais, cindidas desde 1054. Na encíclica In Suprema Petri, publicada em 6 de janeiro de 1848, Pio IX faz um urgente convite às Igrejas separadas do oriente para que voltem à unidade da Igreja católica. O que, na sua visão, ocorreria quando as comunidades orientais reconhecessem o "erro" em suas doutrinas e procurassem a Sede papal, que se dispunha a ajudá-los com os pontos que ainda permanecessem "incertos pela situação desfavorável do passado ou foram fixados de modo não-orgânico". (PIO IX, [1848], 1999, p. 111)

O reforço da uniformidade da doutrina, do cuidado e do zelo pela Tradição passava pela defesa dos valores cristãos pelos príncipes, a quem teria sido confiado o poder "não somente para o governo do mundo, mas sobretudo para a defesa da Igreja (...)" (PIO IX, [1846], 1999, p. 98). Tal consideração

\footnotetext{
13 Um exemplo do papel dos leigos na dinâmica da Igreja expressa-se no pedido do papa Pio IX aos bispos, registrado na encíclica Apostolica Nostra Caritatis, onde, diante dos supostos "graves" problemas enfrentados pela Igreja, recomendava a "verdadeira penitência", tentando aplacar com "com súplicas, jejuns, esmolas e outras obras de piedade a cólera do Senhor provocada pelos delitos dos homens”. (PIO IX, [1854], 1999, pp. 162-163)
} 
demonstra o peso que o princípio de legitimidade ocupava no papado de Pio IX, sendo esta uma das razões pelas quais a Igreja Católica entrou em conflito com o nacionalismo italiano, durante a chamada "Questão Romana".

Este problema territorial é decisivo, uma vez que a posse de territórios foi uma das razões determinantes para o crescimento do poder papal e da Igreja como instituição, da mesma forma como se trata de um dos elementos que constituem sua autoconsciência e que determina as estratégias que empreende ${ }^{14}$. Os argumentos para a manutenção dos territórios se baseiam na Tradição seja através da suposta "Doação de Constantino" (KÜNG, 2012, p. 88) ou no acordo entre o papa Estevão II e Pepino, o "Breve", em 754, em nome da liberdade de ação papal (MARTINA, 2005, p. 226) -, sendo desenvolvidos por Pio IX na encíclica Qui nuper per italiam, de 18 de junho de 1859. Nesta, ao reprovar e lamentar os atos de rebelião, declarava que "o principado civil é necessário a esta Santa Sé, para que exerça sem impedimento, para o bem da religião, a sagrada potestade (...) que os pervertíssimos inimigos da Igreja de Cristo se esforçam por solapar". (PIO IX, [1859], 1999, p. 215)

O problema se relacionava, ainda, à queda de prestígio da Igreja nos territórios retirados de seu dominio. No primeiro período de fuga do $\mathrm{papa}^{15}$, foram negociadas entre o ministério da Justiça e a Câmara, as Leis Siccardi, que buscavam a laicização do Estado, por meio da abolição do foro eclesiástico, das imunidades dos religiosos, além de iniciar a preparação em torno da regulamentação do contrato de casamento civil (ZAGHENI, 2011, pp. 128-129). Na concepção registrada na encíclica Nostis et nobiscum, a Igreja Católica teria protegido a Itália contra "tantas espessas trevas do erro" e embora estivesse em meio às ruínas "daquele antigo império" e sob o perigo das invasões bárbaras, podia "presidir com a divina religião mais extensa e estavelmente do que com a dominação terrena exercida no passado." (PIO IX, [1849], 1999, pp. 131-132)

14 Segundo Casanova, na segunda metade do século VI, as conquistas na península itálica, juntamente com a ameaça de invasões vindas do oriente criaram "as condições geopolíticas para o desenvolvimento da soberania papal sobre a Itália Bizantina, isto é, o centro e o sul da Península Itálica e a Sićlia", levando, desde então, o papado a insistir "na necessidade de manter a soberania territorial sobre os Estados Papais a fim de preservar sua autonomia espiritual" (CASANOVA, 2010, p. 21)

15 Pio IX retirou-se de Roma em novembro de 1848, retornando apenas em abril de 1850 , pois, segundo Zagheni, queria "evitar que sua permanência em Roma fosse interpretada como uma confirmação do novo governo radical; porque se sentia desprovido dos meios idôneos para retomar o controle político da situação; porque esperava evitar um derramamento de sangue." (ZAGHENI, 2011, p. 127) 
Foi no curso da anexação dos territórios papais que se retomou a proposta de reunir em um só documento os supostos "erros" da época, através do chamado Syllabus (ZAGHENI, 2011, p. 139): elenco condenatório composto de 84 proposições concisas, promulgado em anexo à encíclica Quanta Cura, em 8 de dezembro de 1864. Neste documento, a crítica de Pio IX se alinha aos posicionamentos de seus antecessores, contra as "heresias" e os "erros" "16, frutos das

malvadas tramas dos ímpios, que, como vagas de mar tempestuoso, espumam as próprias torpezas e, prometendo liberdade, sendo escravos da corrupção, com suas enganadoras opiniões e com danosíssimos escritos procuram demolir os fundamentos da religião católica e da sociedade civil, destruir todo tipo de virtude e justiça, corromper as mentes e os corações de todos, desencaminhando os incautos e especialmente a inexperiente juventude da reta disciplina dos costumes, corrompendo-a miseravelmente, fazendo-a cair nos laços do erro, e, enfim surrupiando-a do seio da Igreja católica. (PIO IX, [1864], 1999, p. 249)

Segundo a Encíclica, tais "erros" expressavam-se por meio do naturalismo ${ }^{17}$, da liberdade de consciência, da negação da lei segundo a qual as atividades servis eram proibidas em determinados dias em favor do culto a Deus, da defesa do casamento civil, da submissão da Igreja, dos atos e Decretos papais à sanção e aprovação, "ou ao menos do consentimento da autoridade civil” (PIO IX, [1864], 1999, pp. 253- 254). Em resumo, combatia "tudo o que se opõe ao dogma católico da plena autoridade do bispo de Roma divinamente conferida de apascentar, reger e governar a Igreja universal”. (PIO IX, [1864], 1999, pp. 254- 255)

16 Apesar de separar a condenação categorizando-a em "heresias" e "erros", Pio IX não aponta qual o critério utilizado. Sabe-se que a primeira remonta ao Medievo e, pela definição fornecida pelo cânon 751 do Código de Direito Canônico, refere-se à "negação pertinaz, depois de recebido o baptismo, de alguma verdade que se deve crer com fé divina e católica, ou ainda a dúvida pertinaz acerca da mesma”. (CÓDIGO DE DIREITO CANÔNICO, 1983, p. 138). Desta forma, acredita-se que Pio IX teria qualificado por "heresia" os desvios internos ao catolicismo, ao passo que os "erros" seriam incorreções provenientes de instâncias não católicas, o que demonstraria a percepção do papa de que a Igreja, embora nutrisse uma pretensão universalista, não era unanimidade, diferentemente do contexto da Idade Média - por isso o deslocamento dos conceitos.

17 Que seria a defesa do ordenamento social prescindindo da religião, ou, conforme aponta Pio IX, sem distinguir a "verdadeira” religião das demais. (PIO IX, [1864], 1999, p. 250) 
É notável que a Quanta Cura possua uma visão mais dura e combativa aos supostos "erros da modernidade", relativamente à Encíclica gregoriana. $\mathrm{O}$ que se explica pela diferença de conjunturas nas quais foram elaborados cada um dos documentos: enquanto a Mirari Vos estava imiscuída em uma atmosfera de restauração, a década de 1860 via-se dividida por facções liberais dentro da própria Igreja e pelos movimentos nacionalistas de unificação dos reinos italianos. (MARTINA, 2005, p. 239; ZAGHENI, 2011, p.140)

Quanto ao Syllabus, sintetizava condenações de 32 Encíclicas, cartas e alocuções próprias, sendo um grande resumo da doutrina ultramontana em vigor. Divide-se em 10 parágrafos ${ }^{18}$, dirigidos contra todos os "princípios imortais de 1789", condenáveis não só enquanto doutrinas, mas pela concepção de vida que emanam, que "rejeita ou limita os direitos de Deus sobre as criaturas" (MARTINA, 2005, pp. 240- 241). Dentre estes, destacamse os erros que se referem ao liberalismo moderno, principalmente o de número 80, que rejeita a possibilidade de reconciliação do Papa com o progresso, o liberalismo e a civilização moderna (PIO IX, [1864], 1999, p. 275). Esta afirmação remete à alocução Iamdudum cernimus, de 18 de março de 1861, que tomava tais tendências modernas como sinônimos de indiferentismo religioso, de modo que "a Igreja não podia reconciliar-se com esse progresso, com esse liberalismo e com essa civilização”. (ZAGHENI, 2011, p. 142)

Apesar da rigidez nas condenações, Pio IX não aponta um caminho prático a seguir. O que não impediu que o documento fosse tomado como base pela comissão teológica que preparou os documentos a serem discutidos no Concílio Vaticano I - reunido entre 08 de dezembro de 1869 a 18 de dezembro de 1870 - o qual, juntamente com o Syllabus e o dogma da Imaculada Conceição, destinava-se a realizar contra o racionalismo "o mesmo que o Concílio de Trento havia feito contra o protestantismo”. (SOUZA; GONÇALVES, 2013, p. 66)

Consolidava-se, desse modo, a postura ortodoxa da Igreja, reativa às principais tendências da modernidade ocidental. Este "paradigma tridentino", embora herdado pelo papado de Leão XIII, sofreria importantes

18 Os quais se dedicam aos seguintes temas: Panteísmo, Naturalismo e Racionalismo absoluto; Racionalismo moderado; Indiferentismo e a falsa tolerância em matéria religiosa; Socialismo, Comunismo, Sociedades Secretas, Associações Bíblicas e Sociedades Clérico-Liberais; erros sobre a Igreja e seus direitos; erros da Sociedade civil em si e suas relações com a Igreja; erros a respeito da ética natural e Cristã; erros a respeito do matrimônio cristão; erros relativos à soberania temporal do Romano Pontífice e erros que se referem ao liberalismo moderno. 
reconfigurações, sinalizando com uma maior abertura no sentido de redefinir a missão da Igreja perante a sociedade moderna e secular.

\section{O "paradigma leonino": a Igreja na modernidade}

Gioacchino Pecci, o futuro Papa Leão XIII (1878-1903), nasceu, na Itália, em 1810 e, desde muito jovem, frequentou colégios voltados à preparação de diplomatas e administradores pontifícios, sendo enviado pelo Papa Gregório XVI a Benevento como delegado apostólico, logo após sua ordenação, em 1837, a fim de pacificar os conflitos que questionavam a autoridade pontifícia. (CAMACHO, 1995).

Devido à habilidade na administração diplomática e à vasta cultura intelectual do jovem padre, fora indicado para a nunciatura em Bruxelas e, posteriormente, para ocupar o mesmo cargo em Londres, onde teve contato com os problemas sociais acarretados pelo capitalismo industrial. Mais tarde, sua vivência enquanto Bispo de Perúgia, também contribuiu para formar suas opiniões acerca dos problemas do mundo moderno, os quais expôs em suas correspondências pastorais (ZAGHENI, 2011, p. 170). De fato, sua sensibilidade diante das consequências das transformações sociais fizeram com que o corpus documental de seu pontificado abordasse assuntos os mais variados, tais como: matrimônio, missões, família, Estado, filosofia, sociedade, etc., podendo-se dizer que o Pontífice inaugurou um estilo de magistério que perdura até os dias de hoje ${ }^{19}$.

No dia 20 de fevereiro de 1878, após um rápido conclave, Pecci assume a Cátedra petrina. O contexto ressoava o clima de condenação e de fechamento da Igreja ao mundo moderno, as tensões em torno da "Questão Romana", o anticlericalismo que se manifestava por meio de medidas legislativas e de protestos no território italiano contra a Igreja Católica e o $\mathrm{Papa}^{20}$, em boa medida legitimados pela ascensão política de maçons e liberais. Tudo isso, contribuindo para tensionar as relações entre o Estado e a Cúria romana e alimentar as incertezas sobre o futuro do novo pontificado.

Leão XIII não tardou a reiterar o clima vigente, mediante o gesto

19 Um exemplo recente desta diversidade de temas aos quais os papados discutem pode ser visto nas intenções mensais de oração que o Papa Francisco pede à Igreja. Em novembro de 2020, o atual pontífice dedicou a oração à relação entre o bem comum, a robótica e a inteligência artificial. https://www.vaticannews.va/pt/papa/news/2020-11/papafrancisco-video-oracao-novembro-inteligencia-artificial.html

20 Um dos mais marcantes aconteceu durante o cortejo fúnebre dos restos mortais do papa Pio IX ao cemitério de Verano. (MARTINA, 2014, p. 12) 
simbólico de dar a primeira benção apostólica sem aparecer no balcão externo da Basílica de São Pedro, assim como pela Non Expedit, que determinava a abstenção de voto dos católicos italianos (MARTINA, 2014, p. 15). Poucos meses após assumir a cátedra petrina, publicou sua primeira encíclica - a Inscrutabili Dei Consilio, em 21 de abril de 1871 -, referindo-se aos supostos males que acometiam a sociedade, descritos em termos muito semelhantes aos seus predecessores:

a teimosia de inteligências intolerantes a toda submissão legítima; o fomento perene às discórdias, das quais surgem as contendas intestinas, e as guerras cruéis e sangrentas; o desprezo a toda lei de moralidade e justiça; a cobiça insaciável dos bens caducos e o menosprezo dos bens eternos, estimula a louco furor que leva tantos infelizes a procurar a morte; a administração inconsulta, o esbanjamento, a malversação dos bens públicos; e até a imprudência daqueles que com pérfido engano querem ser tidos como defensores da pátria, da liberdade e de todo direito. (LEÃO XIII, [1878], 2005, pp. 13- 14)

Como inimigos da Igreja católica, o papado leonino elegia o socialismo, o comunismo ${ }^{21}$ e o niilismo, considerados como caminhos para a inevitável ruína da sociedade, os quais, conforme registrado na encíclica Quod Apostolici Muneris, de 28 de dezembro de 1878, encontravam-se

espalhados por todo o mundo e ligados entre si por vínculos de conspiração iníqua, já não procuram a impunidade nas trevas de conventículos ocultos, mas saindo aberta e insolenemente para a luz do dia, se esforçam por conseguir o propósito, já concebido desde muito tempo, de sacudir o próprio fundamento do consórcio civil. (LEÃO XIII, [1878], 2005, pp. 38- 39)

A origem destas tendências, assim como da própria ideologia liberal considerada expressão do espírito da Revolução Francesa - são reportadas ao princípio protestante do livre exame (CAMACHO, 1995, p. 75), o qual se vincula ao "espírito de novidade" instituído desde o século XVI. Na encíclica Diuturnum Illud, de 29 de junho de 1881, a Reforma protestante é

21 Conforme Mendes, Oliveira e Perin o Socialismo e o Comunismo haviam sido condenados pelo papa Pio IX em quatro ocasiões: na encíclica Qui Pluribus, na Nostis et Nobiscum na Quanta Cura e no Syllabus, tratando-os em bloco juntamente com outros supostos erros adversários da religião. O diferencial de Leão XIII seria considera-los separadamente. (MENDES; OLIVEIRA; PERIN, 2016, pp. 278- 279) 
A Igreja Católica perante a Modernidade: 349 uma análise das encíclicas papais no século XIX

relatada como o momento a partir do qual "a multidão não somente quis dar a si mesma uma liberdade mais ampla do que conveniente, mas pareceu também querer forjar a seu talante a origem e a constituição da sociedade civil”. (LEÃO XIII, [1881], 2005, p. 151)

A recusa ao liberalismo e ao socialismo pautava-se, também, no fato de que ambos os regimes recusavam a obediência à autoridade legítima, representada pela Igreja. Na encíclica Immortale Dei, apresenta o homem constituído enquanto "ser social" pela Providência, destinado a "se unir aos seus semelhantes, numa sociedade tanto doméstica como civil, única capaz de fornecer o que é preciso para a perfeição da existência" (LEÃO XIII, [1885], 2005, p. 239). Esta sociedade teria sua regência derivada de Deus - "o verdadeiro e soberano Senhor das coisas" (LEÃO XIII, [1885], 2005, p. 239) - e, inspirada no modelo de "sociedade perfeita", não estaria isenta das hierarquias. Ao contrário disto, reforça a encíclica Quod Apostolici Muneris, nela os homens seriam "distintos por dignidade, direitos e poder", assemelhando-se à diversidade encontrada no "reino celeste" e na Igreja, onde há variedade de ministérios (LEÃO XIII, [1878], 2005, p. 42).

Esta mesma concepção o levava a prescrever os termos ideais mediante os quais se daria a relação entre Estado e Igreja, na sociedade moderna. Segundo o Pontífice, o Estado deveria "prestar culto divino, como também o respeito à Igreja católica, enquanto "Sociedade Perfeita” (LEÃO XIII, [1885], 2005, p. 243), havendo entre ambos os poderes um sistema de relações bem ordenado, não sem analogia com aquele que, no homem, constitui a união da alma com o corpo. (LEÃO XIII, [1885], 2005, pp. 244- 245)22

No discurso leonino, porém, a retomada dos valores cristãos incorpora formas inéditas, representadas por ações propositivas, principalmente no que se refere à questão social (ZAGHENI, 2011, p. 52). Ou seja: mantinha-se o conteúdo de cunho ultramontano, embora apontasse bases para sua superação. Tais ações representam estratégias de "flexibilização", as quais, sem abrirem mão da normatização representada pela aplicabilidade da doutrina à sociedade civil, propunham situar por meio da temporalização a "atividade da Igreja no curso histórico", desde que não entrasse em conflito com a lei natural

\footnotetext{
22 Este pensamento apresentado na Immortale Dei é retomado na encíclica Sapienciae Christianae, na qual afirma que, devido à natureza da instituição católica enquanto sociedade perfeita, ela se abstêm de seguir partidos políticos ou de apontar determinada forma de governo, “antes aprova todos os diversos sistemas políticos, contanto que respeitem a religião e a moral cristã” (LEÃO XIII, [1890], 2005, p. 398).
} 
(FANTAPPIÈ, 2012, p.335). Da mesma forma, o modo "como é dito"23 revela algumas diferenças importantes do discurso leonino em relação aos seus predecessores, enfatizando a estratégia da adaptação e da conciliação dos valores cristãos à sociedade moderna, matizando o tom autoritário e condenatório. O próprio Pontífice reconhece que, por diversas vezes, tratou das assim chamadas "liberdades modernas", concluindo que "o que estas liberdades contém de bom, é tão antigo como a verdade, tudo isso a Igreja o aprovou sempre com ardor, e o admitiu efetivamente na prática". (LEÃO XIII, [1888], 2005, p. 312)

Desse modo, é possível concordar que, embora fossem evidentes os “apadrinhamentos” de Leão XIII à ideia do Syllabus, é na leitura de mundo e no teor das decisões que a diferença entre os dois papados se faz presente (MARTINA, 2014, p. 53). Neste sentido, a análise das encíclicas por ele emitidas, a partir da perspectiva da interdiscursividade e da intertextualidade, é reveladora sobre o modo como seu pensamento se estrutura a partir de contingências e experiências singulares, orientadoras de uma concepção acerca da missão social da Igreja que, embora delineada no âmbito da longa trajetória do "paradigma tridentino", a ele se opõe em aspectos essenciais, configurando o que pode ser denominado de "paradigma leonino", ou “tomista-leoniano" (ANDRADE, 2010). Tal paradigma adequava-se a uma conjuntura em que a consolidação da sociedade moderna tornara-se um fato inegável, diante do qual "não se colocava mais a ilusão de um retorno ao Antigo Regime", exigindo "uma redefinição do paradigma vigente" inspirado nas proposições do Syllabus de Pio IX. ${ }^{24}$

Estas novidades do discurso leonino, bem como da autocompreensão da Igreja católica, estão melhor formuladas e sistematizadas na encíclica Rerum Novarum, lançada em 15 de maio de 1891 e introduzida pela expressão "Das Coisas Novas". Este documento pode ser considerado um ponto de chegada do pensamento desenvolvido pelos movimentos católicos-sociais, ao mesmo tempo que inaugura uma série de escritos elaborados pelo magistério católico

23 Neste sentido, vale notar que o “ 'como é dito' é tão importante, senão mais, quanto 'o que é dito’, devendo-se conceber a fabricação dos discursoscomo resultado de uma prática (CERTEAU apud PIRES, p. 37).

24 Principalmente na rejeição da separação entre Estado e Igreja, da liberdade religiosa e do princípio de soberania popular. (ANDRADE, 2010, p. 183) 
a respeito da "questão social" na sociedade moderna e industrial, formando a chamada Doutrina Social da Igreja ${ }^{25}$.

Neste sentido, a Rerum Novarum tornou-se "um 'paradigma permanente' para o desenvolvimento da doutrina social" e, no seu âmbito, da questão operária (JOÃO PAULO II apud PONTIFÍCIO CONSELHO JUSTIÇA E PAZ, 2011, p. 60 ${ }^{26}$, principalmente no que toca à concepção de que a economia deveria estar a serviço do homem e não o contrário (DANIELROPS, 2006, p. 193). Segundo o Pontífice, a escolha deste tema se justificava pela chegada da "sede de inovações, que há muito tempo se apoderou das sociedades, e as tem numa agitação febril", de tal forma que:

Efetivamente, os progressos incessantes da indústria, os novos caminhos em que entraram as artes, a alteração das relações entre os operários e os patrões, a afluência da riqueza nas mãos de um pequeno número, ao lado da indigência da multidão, a opinião enfim mais avantajada que os operários formam de si mesmos e a sua união mais compacta, tudo isso, sem falar da corrupção dos costumes, deu em resultado final um temível conflito. (LEÃO XIII, [1891], 2005, pp. 419-420) (1891)

É esta, portanto, a sociedade que Leão XIII se propunha a reformar, aliando-se à tendência geral de movimentos anticapitalistas, surgidos nas últimas décadas do século $X I X$ e primeiros anos do século XX, sendo a corrente católica a mais organizada e bem-sucedida (MENDES; OLIVEIRA; PERIN, 2016, p. 274). Esta tendência distinguia-se tanto do liberalismo exacerbado - associado à "usura voraz" que teria agravado a miséria, juntamente com "o monopólio do trabalho e dos papéis de crédito, que se tornaram o quinhão de um pequeno número de ricos e de opulentos, que impõem assim um jugo quase servil à imensa multidão dos proletários" (LEÃO XIII, [1891], 2005, p. 421) -, quanto do

25 Segundo o Compêndio da Doutrina Social da Igreja: "Os princípios afirmados por Leão XIII serão retomados e aprofundados pelas encíclicas sociais sucessivas. Toda a doutrina social poderia ser entendida como uma atualização, um aprofundamento e uma expansão do núcleo original de princípios expostos na 'Rerum Novarum' " (PONTIFÍCIO CONSELHO JUSTIÇA E PAZ, 2011, p. 60).

26 "A ideia de 'doutrina social' da Igreja é tema importante em si mesmo, porque acompanhou a ação pastoral da Igreja no mundo moderno nos últimos cem anos, marcando uma presença e uma ação pontual e preciosa e interpretando os momentos mais significativos dos acontecimentos sociais, econômicos e políticos. Através dessas intervenções, a Igreja também contribuiu - de maneira relevante - para formar a própria consciência da história contemporânea", bem como sua autocompreensão, ressignificada diante das novas demandas socioculturais. (ZAGHENI, 2011, p. 189) 
socialismo marxista, referido como o "falso remédio". Isto porque, além de ineficaz, era injusto por "violar os direitos legítimos dos proprietários, viciar as funções do Estado e tender à subversão completa do edifício social." (LEÃO XIII, [1891], 2005, p. 421)

Assim, Leão XIII considera que a finalidade deste aprofundamento da questão operária pela Encíclica era "expor os princípios de uma solução conforme à justiça e à equidade” (LEÃO XIII, [1891], 2005, p. 420). Apesar de reconhecer as dificuldades em especificar os direitos e deveres concernentes à riqueza e ao proletariado, ao capital e ao trabalho, é neste ponto que o paradigma leonino expõe seu lado prático, bem como a via da adaptação dos valores cristãos à sociedade secularizada. Para tanto, propõe a articulação de três instituições: a Igreja, o Estado e as Associações de patrões e operários ${ }^{27}$, que embora diferenciadas juridicamente, deveriam estar em permanente diálogo para o bem-estar social.

Neste sentido, propunha o intercâmbio de informações e ideias com as periferias do mundo católico - as novas tendências do catolicismo social -, assim como apostava na capacidade do conteúdo religioso prover a solução para a questão operária, por meio do congraçamento/cooperação entre as classes promovido pelas Associações ${ }^{28}$ - e destas com o Estado. Ambos seriam conduzidos pelos conteúdos religiosos ditados pela Igreja católica, cujos instrumentos "são os únicos aptos" e "capazes de levar o homem a obedecer às imposições do dever, a dominar as suas paixões, a amar a Deus e ao seu próximo com uma caridade sem limites" (LEÃO XIII, [1891], 2005, p. 437). Neste sentido, partia do princípio de que "não cabe à Igreja indicar por quais caminhos concretos a sociedade deve encaminhar-se para resolver os problemas do trabalhador", mas, sim "afirmar os princípios básicos de ação e orientar as consciências” (ZAGHENI, 2011, p. 198).

27 Na sua visão, o direito de associação, assim como o de propriedade, seria natural ao homem e justificado pelas escrituras, onde se lê a máxima: “Mais valem dois juntos que um só, pois tiram vantagem da sua associação. Se um cai, o outro sustenta-o. Desgraçado do homem só, pois, quando cair, não terá ninguém que o levante"' ((LEÃO XIII, [1891], 2005, p. 452)

28 As associações assumiriam diversas modalidades de auxílio entre elas as: os "socorros mútuos; as diversas instituições, devidas à iniciativa particular, que têm por fim socorrer os operários, bem como as suas viúvas e órfãos, em caso de morte, de acidentes ou de enfermidades; os patronatos que exercem uma proteção benéfica para as crianças dos dois sexos, os adolescentes e os homens feitos. (LEÃO XIII, [1891], 2005, p. 451). 
O paradigma leonino definia-se, portanto, na confluência de tendências que vinham sendo afirmadas desde antes - pelo magistério da Igreja, pelo catolicismo social e por tendências liberais e socialistas -, reinterpretadas à luz do advento da sociedade de classes, do amadurecimento do capitalismo e do processo de secularização. Ao enunciar os desafios e propor soluções, Leão XIII abria um novo campo de possibilidades histórias, no âmbito do qual a Igreja católica assumia uma função social, "afirmando princípios de valor universal e de perene atualidade, em favor do homem que trabalha e de seus direitos". (PONTIFÍCIO CONSELHO JUSTIÇA E PAZ, 2011, p. 160)

\section{Considerações Finais}

Refletir sobre este percurso trilhado pela Igreja Católica no decorrer dos três pontificados analisados é corroborar os estudos sobre o papel e as reconfigurações da religião e seus agentes em meio aos processos históricos de secularização. Trata-se de reconhecer a vivacidade desta Instituição, ressaltando sua capacidade de atualização, seja em termos normativos, seja, sobretudo, no que concerne às estratégias utilizadas para se manter influente e atuante. Conforme Martina:

os pontífices mudaram de rota muito rapidamente, dando prova da formidável capacidade da Igreja de se adaptar às novas condições, de encontrar sempre novos compromissos, encobrindo suas retiradas estratégicas com interpretações elásticas das drásticas condenações precedentes, jamais retiradas explicitamente, mas de fato abrandadas e gradualmente abandonadas. (MARTINA, 2005, p. 247)

Além disso, conforme argumentado introdutoriamente, as permanentes atualizações do discurso oficial da Igreja católica nos colocam em contato com as diferentes e simultâneas durações inscritas numa mesma moldura temporal. Neste caso, a avalanche de eventos - aqui tomados como sintomas e aceleradores das transformações vivenciadas pelo século XIX -, demandou respostas cada vez mais imediatas da Igreja, redefinindo suas estratégias discursivas e de ação, embora em nível da doutrina e da normatividade as mudanças não se dessem de forma tão rápida. O que torna a distância entre experiências e expectativas - ou ainda, entre a tradição herdada e a “experiência de surpresa permanente" (KOSELLECK, 2006, p. 289) que caracteriza a modernidade - mais notáveis, primeiramente em nível dos discursos, que ao serem enunciados liberam e orientam prognósticos capazes de alterar as próprias condições de sua emergência. 
Neste sentido, o que singulariza cada um dos pontificados analisados é, precisamente, este poder de "elaborar acontecimentos passados" a partir de circunstâncias presentes, que ao abrir um novo campo de ação e previsões para a Igreja católica, libera expectativas que já não "decorrem apenas da experiência” (KOSELLECK, 2006, p. 313). Um exemplo concreto disso, seria a recepção que a articulação entre Igreja, Estado e massas operárias, enunciada pela Rerum Novarum, encontraria no fascismo italiano, embora as reais intenções de Mussolini tenham sido descobertas e condenadas rapidamente pelo Magistério. (MANOEL, 2004, p. 144)

\section{Referências}

ANDRADE, Paulo Fernando Carneiro de. Democracia e Doutrina Social da Igreja. In.: LESBAUPIN, Ivo; PINHEIRO, José Ernanne (Orgs.). Democracia, Igreja e cidadania. São Paulo: Paulinas, 2010. pp. 171- 210.

BARNABÉ, Gabriel Ribeiro. Summi Pontificatus: As Relações Internacionais da Santa Sé sob Pio XII. 2011. 291 f. Tese (Doutorado em Filosofia). Instituto de Filosofia e Ciências Humanas, UNICAMP. Campinas.

BATISTA, Carolina de Almeida. Da Quanta Cura (1864) de Pio IX a Rerum Novarum (1891) de Leão XIII: Relações entre permanências e busca por adaptações. 2013. 143 f. Dissertação (Mestrado em História). Faculdade de Ciências e Letras. Universidade Estadual Paulista, Assis.

BRANDÃO, Helena Hathsue Nagamine. Introdução à análise do discurso. 2. Ed. rev. Campinas: Editora da Unicamp, 2004

CALDEIRA, Rodrigo Coppe. Bases temporais para o estudo histórico da Igreja Católica do século XX. Horizonte, Belo Horizonte, v. 15, n. 47, p. 770-796, jul./ set.2017.

CAMACHO, Ildefonso. Doutrina Social da Igreja: abordagem histórica. São Paulo: Loyola, 1995.

CARLETTI, Anna. O internacionalismo vaticano e a nova ordem mundial: a diplomacia pontifícia da Guerra Fria aos nossos dias. Brasília: FUNAG, 2012.

CASANOVA, José. A globalização do catolicismo e o Retorno a uma Igreja Universal. Rever, São Paulo, ano 10, p. 17- 45, dez 2010

CODIGO DE DIREITO CANÔNICO. Disponível em: http://www.vatican.va/archive/codiuris-canonici/portuguese/codex-iuris-canonici_po.pdf Acesso em: 29 Jul. 2018.

COELHO, Allan da Silva. Secularização e Laicidade: abordagens destoantes para pensar a modernidade. Impulso, Piracicaba, 26(67), pp- 85- 98, set- dez 2016.

COMBY, Jean. Para ler a história da Igreja II: do século XV ao século XX. Trad. Maria Stela Gonçalves, Adail V. Sobral. São Paulo: Loyola, 1994. 
A Igreja Católica perante a Modernidade: 355 uma análise das encíclicas papais no século XIX

CONTIERO, Tiago Tadeu. O mundo na Igreja e a Igreja no Mundo: Reflexões sobre o Concílio Vaticano II e a modernidade. 2017. 262 f. Tese (Doutorado em Ciência da Religião). Pontifícia Universidade Católica de São Paulo. São Paulo.

CORDI, Cassiano. O Tradicionalismo na República Velha. 1984. 189f. Tese. (Doutorado em Filosofia). Universidade Gama Filho, Rio de Janeiro.

DANIEL-ROPS, Henri. A Igreja das Revoluções: I. Diante de novos destinos. Vol.VIII. São Paulo: Quadrante, 2003. (Coleção História da Igreja de Cristo)

DANIEL-ROPS, Henri. A Igreja das Revoluções: II. Um combate por Deus. Vol. IX. São Paulo: Quadrante, 2006. (Coleção História da Igreja de Cristo)

DI STEFANO, Roberto. Modernidad religiosa y secularización em la Argentina del siglo XIX. In: MARANHÃO FILHO, Eduardo Meinberg de Albuquerque (org.). Política, Religião e diversidades: Educação e Espaço Público (vol 1). Florianópolis: ABHR/ Fogo, 2018, p. 133- 147.

FANTAPPIÈ, Carlo. La Santa Sede e il Mondo in prospettiva storico- giuridica. In: Rechtgeschichte Legal History. n.s. 20, pp. 332- 338, 2012.

GREGÓRIO XVI, Papa. Encíclica Aquele Deus: Palavras de reconhecimento pela salvação do poder temporal (1831). In.: IGREJA CATÓLICA. Documentos de Gregório XVI e de PIO IX (1846- 1878). Org. Geral Lourenço Costa. Trad. Darci L. Marin. São Paulo: Paulus, 1999. pp. 11- 16 (Coleção Documentos da Igreja vol. 6)

GREGÓRIO XVI, Papa. Encíclica As armas valorosas: A obediência decida à Santa Sé Romana (1831). In.: IGREJA CATÓLICA. Documentos de Gregório XVI e de PIO IX (18461878). Org. Geral Lourenço Costa. Trad. Darci L. Marin. São Paulo: Paulus, 1999. pp. 17- 19. (Coleção Documentos da Igreja vol. 6)

GREGÓRIO XVI, Papa. Encíclica Cum Primum Ad Aures: A obediência devida às autoridades constituídas (1832). In.: IGREJA CATÓLICA. Documentos de Gregório XVI e de PIO IX (1846- 1878). Org. Geral Lourenço Costa. Trad. Darci L. Marin. São Paulo: Paulus, 1999. pp. 20- 24. (Coleção Documentos da Igreja vol. 6)

GREGÓRIO XVI, Papa. Encíclica Mirari vos: Sobre os principais erros de seu tempo (1832). In.: IGREJA CATÓLICA. Documentos de Gregório XVI e de PIO IX (1846-1878). Org. Geral Lourenço Costa. Trad. Darci L. Marin. São Paulo: Paulus, 1999. pp. 25- 42. (Coleção Documentos da Igreja vol. 6)

HOBSBAWM, Eric J. A era das revoluções, 1789-1848. 34. ed. Rio de Janeiro: Paz e Terra, 2014

KOSELLECK, Reinhart. Futuro Passado: Contribuição à semântica dos tempos históricos. Trad. Wilma Patrícia Maas, Carlos Almeida Pereira; revisão César Benjamin. Rio de Janeiro: Contraponto-Ed. PUC-Rio, 2006.

KOSELLECK, Reinhart. Uma História dos Conceitos: problemas teóricos e práticos. Estudos Históricos, vol. 5, n. 10, 1992, p. 134-146.

KÜNG, Hans. A Igreja tem salvação? 1. Ed. São Paulo: Paulus, 2012. 
LEÃO XIII, Papa. Encíclica Diunturnum Illud: Origem do poder civil (1881). In: IGREJA CATÓLICA. Documentos de Leão XIII (1878- 1903). Trad. Honório Dalbosco, Lourenço Costa. São Paulo: Paulus, 2005, 149- 163. (Coleção Documentos da Igreja vol. 12)

LEÃO XIII, Papa. Encíclica Immortale Dei: A constituição cristã dos Estados (1885). In: IGREJA CATÓLICA. Documentos de Leão XIII (1878- 1903). Trad. Honório Dalbosco, Lourenço Costa. São Paulo: Paulus, 2005, 237- 264. (Coleção Documentos da Igreja vol. 12)

LEÃO XIII, Papa. Encíclica Inscrutabili Dei Consilio: Início do pontificado (1878). In: IGREJA CATÓLICA. Documentos de Leão XIII (1878- 1903). Trad. Honório Dalbosco, Lourenço Costa. São Paulo: Paulus, 2005, 13- 23. (Coleção Documentos da Igreja vol. 12)

LEÃO XIII, Papa. Encíclica Libertas: A liberdade humana (1888). In: IGREJA CATÓLICA. Documentos de Leão XIII (1878- 1903). Trad. Honório Dalbosco, Lourenço Costa. São Paulo: Paulus, 2005, 311- 341. (Coleção Documentos da Igreja vol. 12)

LEÃO XIII, Papa. Encíclica Quod Apostolici Muneris: Socialismo, comunismo e niilismo (1878). São Paulo: Paulus, 2005. In: IGREJA CATÓLICA. Documentos de Leão XIII (18781903). Trad. Honório Dalbosco, Lourenço Costa. São Paulo: Paulus, 2005, 37- 48. (Coleção Documentos da Igreja vol. 12)

LEÃO XIII, Papa. Encíclica Rerum Novarum: Sobre a condição dos operários (1891). In: IGREJA CATÓLICA. Documentos de Leão XIII (1878-1903). Trad. Honório Dalbosco, Lourenço Costa. São Paulo: Paulus, 2005, 419- 461. (Coleção Documentos da Igreja vol. 12)

LEÃO XIII, Papa. Encíclica Sapientiae Christianae: Os deveres fundamentais dos cidadãos cristãos (1890). In: IGREJA CATÓLICA. Documentos de Leão XIII (1878- 1903). Trad. Honório Dalbosco, Lourenço Costa. São Paulo: Paulus, 2005, 383- 408. (Coleção Documentos da Igreja vol. 12)

MANOEL, Ivan Aparecido. O pêndulo da história: tempo e eternidade no pensamento católico (1800-1960). Maringá: Eduem, 2004.

MARTINA, Giácomo. História da Igreja- de Lutero a nossos dias. Vol. 3: a era do liberalismo. São Paulo: Loyola, 2005.

MARTINA, Giácomo. História da Igreja- de Lutero a nossos dias. Vol. 4: a era contemporânea. Trad. Orlando Soares Moreira. $3^{\mathrm{a} E d}$. São Paulo: Loyola, 2014.

MENDES, Claudinei Magno Magre; OLIVEIRA, Terezinha; PERIN, Conceição Solange Bution. Do Antissocialismo ao Anticapitalismo: um estudo sobre a Rerum Novarum. Revista Brasileira de História das Religiões, ANPUH n. 25, ano IX, pp. 271- 304, maio/agosto de 2016.

MOMIGLIANO, Arnaldo. As raízes clássicas da historiografia moderna. Bauru: EDUSC, 2004.

ORLANDI, Eni Puccinelli. A Linguagem e seu funcionamento. As formas do discurso. $4^{a}$ edição. Campinas: Pontes, 1996.

ORLANDI, Eni Puccinelli. Análise do Discurso: princípios \& procedimentos. $11^{\text {a }}$ edição. Campinas: Pontes, 2013.

PIO IX, Papa. Encíclica Apostolica Nostre Caritatis: Orações pela paz (1854). In.: IGREJA CATÓLICA. Documentos de Gregório XVI e de PIO IX (1846- 1878). Org. Geral Lourenço 
Costa. Trad. Darci L. Marin. São Paulo: Paulus, 1999. pp. 161- 166. (Coleção Documentos da Igreja vol. 6)

PIO IX, Papa. Encíclica In suprema Petri: A unidade da Igreja (1848). In.: IGREJA CATÓLICA. Documentos de Gregório XVI e de PIO IX (1846- 1878). Org. Geral Lourenço Costa. Trad. Darci L. Marin. São Paulo: Paulus, 1999. pp. 108- 120. (Coleção Documentos da Igreja vol. 6)

PIO IX, Papa. Encíclica Nostis et Nobiscum: A condição da Igreja no Estado Pontifício (1849). In.: IGREJA CATÓLICA. Documentos de Gregório XVI e de PIO IX (1846- 1878). Org. Geral Lourenço Costa. Trad. Darci L. Marin. São Paulo: Paulus, 1999. pp. 129- 151. (Coleção Documentos da Igreja vol. 6)

PIO IX, Papa. Encíclica Quanta Cura: condenação e proscrição dos graves erros do tempo presente (1864). In.: IGREJA CATÓLICA. Documentos de Gregório XVI e de PIO IX (1846- 1878). Org. Geral Lourenço Costa. Trad. Darci L. Marin. São Paulo: Paulus, 1999. pp. 248- 259. (Coleção Documentos da Igreja vol. 6)

PIO IX, Papa. Encíclica Qui nuper per Italiam: O principado civil da Sé Apostólica de Roma (1859). In.: IGREJA CATÓLICA. Documentos de Gregório XVI e de PIO IX (1846- 1878). Org. Geral Lourenço Costa. Trad. Darci L. Marin. São Paulo: Paulus, 1999. pp. 215- 216. (Coleção Documentos da Igreja vol. 6)

PIO IX, Papa. Encíclica Qui Pluribus: Erros da época (1846). In.: IGREJA CATÓLICA. Documentos de Gregório XVI e de PIO IX (1846- 1878). Org. Geral Lourenço Costa. Trad. Darci L. Marin. São Paulo: Paulus, 1999. pp. 81- 99. (Coleção Documentos da Igreja vol. 6) PIO IX. Papa. Syllabus (1864). In.: IGREJA CATÓLICA. Documentos de Gregório XVI e de PIO IX (1846- 1878). Org. Geral Lourenço Costa. Trad. Darci L. Marin. São Paulo: Paulus, 1999. pp. 260- 276. (Coleção Documentos da Igreja vol. 6)

PIRES, Tiago. Revisitando a Historiografia Eclesiástica: a superação de uma narrativa Eusebiana. In: BUARQUE, Virgínia A. Castro; (org.). História da historiografia religiosa. Ouro Preto: EDUFOP/ PPGHIS, 2012. pp. 27 - 42.

PONTIFÍCIO CONSELHO JUSTIÇA E PAZ. Compêndio da doutrina social da Igreja. Trad. Conferência Nacional dos Bispos do Brasil. $7^{a}$ ed. São Paulo: Paulinas, 2011.

PRODI, Paolo. Il paradigma tridentino, un'epoca della storia della Chiesa. Brescia: Morcelliana, 2010.

RÉMOND, René. O século XIX: 1815- 1914. 12ªEd. São Paulo: Cultrix. 1997.

SANTIROCCHI, Ítalo Domingos. Questão de Consciência: os ultramontanos no Brasil e o regalismo do Segundo Reinado (1840-1889). Fino Traço: Belo Horizonte 2015.

SANTIROCCHI, Ítalo Domingos. O paradigma tridentino e a Igreja Católica no Brasil oitocentista: modernidade e secularização. Reflexão, Campinas, v.42, n.2, p.169-181, 2017.

SILVA, Tatiane Xavier da; COSTA, Ivandilson. O discurso religioso: aspectos de performatividade, autoritarismo e relações de poder. Linguagem - Estudos e Pesquisas. Vol. 15, n. 02, p. 119-136, jul/dez 2001.

STEIL, Carlos Alberto; HERRERA, Sonia Reyes. Catolicismo e Ciências Sociais no Brasil: mudanças de foco e perspectivas num objeto de estudo. Sociologias, Ano 12, Nº 23,pp. 354-393. 2010. 
SOUZA, Ney; GONÇALVES, Paulo Sérgio Lopes. Catolicismo e sociedade contemporânea: do Concílio Vaticano I ao contexto histórico-teológico do Concílio Vaticano II. São Paulo: Paulinas, 2013. (Coleção História da Igreja)

VATTIMO, Gianni. O fim da Modernidade: niilismo e hermenêutica na cultura pós-moderna. São Paulo: Martins Fontes, 2002.

XAVIER-GUERRA, François. Modernidad e independencias: ensayos sobre las revoluciones hispánicas. Encuentro. 2009.

ZAGHENI, Guido. A Idade Moderna: curso de história da Igreja. Trad. José Maria de Almeida. $2^{a}$ Ed. São Paulo: Paulinas, 2011.

ZANOTTO, Gizele. A análise do discurso como instrumento metodológico para o historiador da religião. In: SILVA, Ana Rosa Cloclet da; DI STEFANO, Roberto (orgs.). História das religiões em perspectiva: desafios conceituais, diálogos interdisciplinares e questões metodológicas. Curitiba: Primas, 2018.

Submetido em: 1-2-2021

Aceito em: 11-10-2021 